\title{
ニューラルネットワークを用いた納期余裕予測による ジョブ・ショップ・スケジューリング
}

\author{
学生員 橋 本 泰 典 (立命館大) \\ 正員渡部透（立命館大） \\ 西川郁子（立命館大) \\ 得丸英勝 (立命館大)
}

\begin{abstract}
Job-Shop Scheduling Using a Neural Network to Estimate Margins to Due-Dates
Y. Hashimoto, Member (Ritsumeikan University), T. Watanabe, Member (Ritsumeikan University),

I. Nishikawa (Ritsumeikan University), H. Tokumaru (Ritsumeikan University)
\end{abstract}

Job-shop scheduling is not easy to be solved analytically, therefore, it is ordinarily solved by computer simulation using heuristic dispatching rules. The SLACK rule to give the priority to the job having the shortest margin to its due-date is effective to keep the due-dates. The margin is simply calculated by subtraction of remained operation-time from the time to the due-date. However, actual margins become shorter than the calculated ones due to the confliction between jobs.

In the preceding paper of authors ${ }^{(16,17)}$, a method to estimate rather accurate margins using two neural networks was proposed in which a three-layer neural network (numbers of neurons; the first layer - the second - the third : 1020-1) estimated the margins and the other three-layer neural network having the composition of 11-20-1 judged the accuracy of the estimation because the reliability of the estimation was low. The estimated margins were used for scheduling using the SLACK rule instead of ones calculated by the ordinary method when its reliability was judged high. In this paper, a method using only a neural network for the estimation of which the organization is more adequately adjusted is proposed. In the proposed method, the neural network having four layers with fewer neurons as 8-8-8-1 learns the margins to due-dates from schedules made by using the ordinary SLACK rule, as human schedulers do. It is verified by scheduling simulation that the proposed method is effective to improve the maximum lateness to due-dates on job-shop schedules. Furthermore, re-learning of the neural network based on schedules made by the above method is revealed to be effective for further improvement of the schedules.

$$
\text { キーワード：ジョブ・ショップ, スケジューリング, ニューラルネットワーク, 生産管理 }
$$

\section{1.まえがき}

近年，消費者それそれの暏好に合うように，多種の製品 を供給する多品種少量生産を行う製造業が增えている。最 近の経済不況に伴って, 生産効率を高內るため, 多品種少 量生産を見直す声もあるが，消費者の意向を無視しては， 新たな製品需要の創出を見逃すなど返って逆勃果で, 時代 の流れに逆行することになるう。むしろ,フレキシブル． オートメーションや, C I M ( Computer I n t e grated Manufacturing) などの技

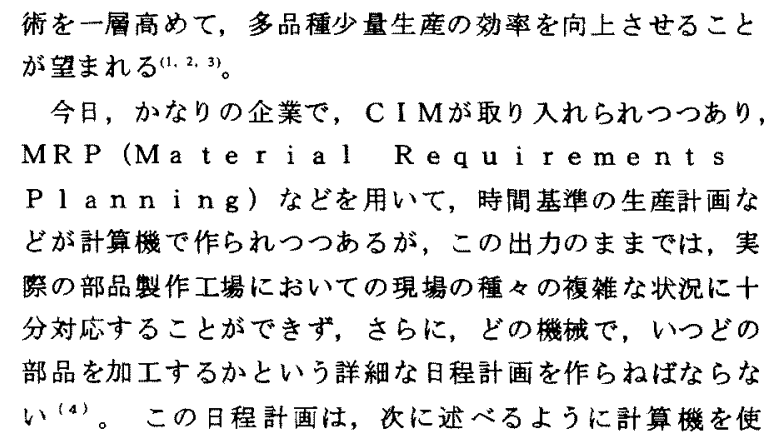


って作られる場合もあるが, 現場の複雑な状况には十分対 応することはできず，日程計画を作成する生産管理者（S $\mathrm{ch}$ e d u l e r s) や現場の班長が計算機出力を手直し したり，直接作ったりする場合がほとんどである(4)。

特に, 多品種少量生産を行う工場においては，制造する 製品あるいは部品（以下ジョブ：J。bと呼称）の種類に よって，製造工程が互いに異なるジョブ・ショップとなる 場合が多いが，一般にジョブ・ショップの日程計画を作る ジョブ・ジョップ・スケジューリング問題は，N Pハード 問題となり，解析的に最適解を得ることが困難であると言 われ，計算機を利用する場合には，発見的差立規則 $(\mathrm{H} \mathrm{e}$ uristic Dispatching Rules, 発見的優先规則とも言う）を用いて，コンピュータ・シミ ニレーションによって淮最適解を求めようとする場合が多 (अ, $6,7,8)$

ここで使われる発見的差立規則としては，F C F S (F i r s t Come First Served; 早<到 着するジョブの順に加工), EDD（E a r l i e s t Due Da $\mathrm{te}$; 納期の短い順)， SPT（Shor t e s t Processing Time；作業時間の短 い順），S L A C K (納期余裕の短い順)，L。OkA h e a d (S LACKR近いが, 近い将来到着するジョブ も考慮する(9)）などが代表的で(7，9，さらにこれらを改良 した種々の方法がある(9 14、18)。特に，S L A C K, L。。

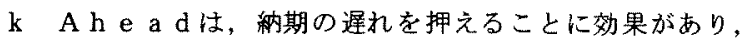
下流にJIT（J u s t I n T i me）を採用する組 立工程などと組み合わせる場合，特に有効である(6.7.9)。

これらの納期余裕を守る上で効果のある方法では，納期 余裕を単純に納期までの時間からそのジョブの残り作業時 間総和を差し引いて計算し（以下，これを理論的納期余裕

$M_{t h}$ と称する)，この理論的納期余裕の短いジョブを 優先的に選んで加工を行う方法をとっている(1.9)。しかし ながら，実際の作業に当っては，一つの機械に对して作業 を待つジョブが複数あるのが普通で，この競合により，作 業を待つジョブが生じる。人閒は, 工場全体の運転状況や ジョブの混み具合などを判断にいれた経験に基づく一種の 勘により，より最適なスケジュールを作ることができる。

そこで，前報に招いて筆者らは，経験を積んだ人間のス ケジュール製作者と同様の働きをする予測システムとして， ニューラルネットワークを用いて，与えられたジョブの状 況と，作成されるスケジュール上の他のジョブとの競合の 影響も考慮した納期余裕（以下，これを理論的納期余裕に 対して実際的納期余裕と称する）との関倸を学習させ，学 習後, これを用いて予測される実際的納期余裕に S L A C Kルールを適用して，納期遅れ改善に効果のあるスケジュ ーリングを行う方法を提案した(15.16.17)。ニューラルネット ワークとしては 3 層構造のものを用いたが，予測唄差など が原因して効果が不十分であり(15)，ニニーラルネットワー クの予測值の正確さを評価する第 2 のニューラルネットワ 一クを導入し，予測値が正確と判断される場合にのみ，二
ューラルネットワークの出力を利用することにより, 実用 的に効果のあるシステムを構成できることを示した (16.17)。

本研究では、ニューラルネットワークの構成を 4 層にす るなど最適な構成を探すことにより，上記の予測值の正確 さを判断する第 2 のニューラルネットワークを用いなくて も，納期遅れ改善に，より効果を上代られる方法について 検討する。なお, ニューラルネットワークの学習を行う侮， 教師信号として何を使うかが問題となる。このニューラル ネットワークの構成の違いの他，前報では，理論的納期余 裕を使う従来の方法で作られたスケジュール上の実祭的納 期余裕を教師信号として用いていた(16, 17)。しかしここの 場合，効率が低いと想定されるスケジュールから得られる データをもとに学習を行うので，これにより十分優れた結 果が導かれるかどうか問題である。そこで, ニューラルネ ットワークを用いて作成されるスケジュールから得られる データを基にニューラルネットワークを再学習する場合の 効果についても検討する。

\section{2. ジョブ ・ ショップのモテリング(9)}

本研究では，N個のジョブをM台の機械で加工する問題 を考える。各ジョブは，M個以下の作業に分解され，各作 業は互いに異なる機械で加工されるものとする。簢単のた め各ジョブは，工場の作業開始時にすへてて到着しているも のとする。また，各ジョブは，合流したり，分岐したりは しないものとする。 $i$ 番目のジョブの作業数 $P_{i}(i=$

$1 ， \cdots, N)$ は， 1 からMまでの整数值を一様乱数に より与え, 更にP ${ }_{i}$ 個の作業の処理順序をランダムに与え る。各作業時間 $T_{i j}(i=1, \cdots, N, j=1, \cdots$, $\left.P_{i}\right)$ は, 5-200 (分) の籍团で一様乱数を用いて決 定する。このときジョブ $i$ の納期 $D_{i}$ は, 次式を用いて決 定する。

$$
D_{i}=\sum_{j=1}^{P_{i}} T_{i j}+\frac{1}{M} \sum_{j=1}^{P_{i}} T_{i j} \cdot \sum_{k=1}^{N} P_{k}+\frac{1}{N M} \sum_{k=1}^{N} \sum_{j=1}^{P_{k}} T_{k j}
$$

\section{3.ニューラルネットワークによる納期 余裕予測の学習}

図 1 は, 本研究で用いた納期余裕を予測するニューラル ネットワークを示し， 8 入力 1 出力で, 中間層は 2 層で構 成され，中間層の各ユニット数はともに 8 ユニットとする。 入力信号には, 各ジョブ $i$ に対して以下に示す 8 要素を用 いる。

$$
\begin{aligned}
& P_{i} \quad: \quad シ ゙ ョ フ ゙ i の \text { 作業数 } \\
& D_{i} \quad: \quad シ ョ ョ フ ゙ i の \text { 納期 } \\
& M_{t h i}: \quad \forall ョ ョ フ ゙ i の \text { 理論的納期余裕 } \\
& =D_{i}-\text {-(検討中の機械の作業開始 } \\
& \text { 時刻) 一 (残り作業時間) } \\
& T_{a \vee i}: \quad シ ゙ ョ フ ゙ i の \text { 平均作業時間 }
\end{aligned}
$$




$$
\begin{aligned}
& M_{a v} v \text { : 平均秋期余裕 (理論的納期余裕の平均值) } \\
& R_{p i}: \because ゙ ョ フ 十 i の \text { 処理回数割合 } \\
& \text { = (ジョブiの作業数) } / \text { (全作業数) } \\
& R_{i} i \quad: \quad \forall ョ ョ フ ゙ i の \text { 加工時閒割合 } \\
& =\text { (ジョプ } i \text { の総作業時間) } ノ(\text { 全作業時間) } \\
& R_{t m i}: \quad シ ゙ ョ フ ゚ i の \text { 作業時間と納期余裕の比 } \\
& =\text { (ジョブ } i \text { の戏り作業時間) /(ジョプi }
\end{aligned}
$$

前報 (16，17)では，10入力 1 出力で 3 層のニューラル． ネットワータ（中間層は 20 ニニット, 入力には本論文の システムの入力の他, ジョブ数と機械数を加えていた）を 用いたが, ネットワークの稢成法, 学習回数などの調查が 十分でなく，期待した納期予測精度が出せなかった。ただ， 予測俱羑に特定の傾向があったため，このネットワークの 予測精度を判定する第 2 のネットワーク（11入力 1 出力 で3屏, 中間層 20 ユニット) を導入し，予測精度を判断 するように学習させ, 第 1 のネットワークの予测精度が高 い場合，この納期予測值を利用し，低い場合，従来のS L A CKルールで用いる方法を取り，一応の成果を得た。し かし，この場合のニューラル・ネットワーク予测值の利用 率は50-30\%と低いものであった。本研究では，棈造 や学習についての試行を十分に行うことにより, ニューラ

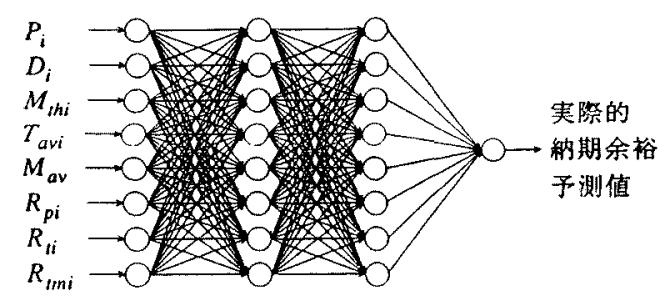

図1 ジョブiの納期余裕を予測するニュー ラルネットワーク

Fig. 1. Neural network for estimating the margin of job $i$ to its due-date.

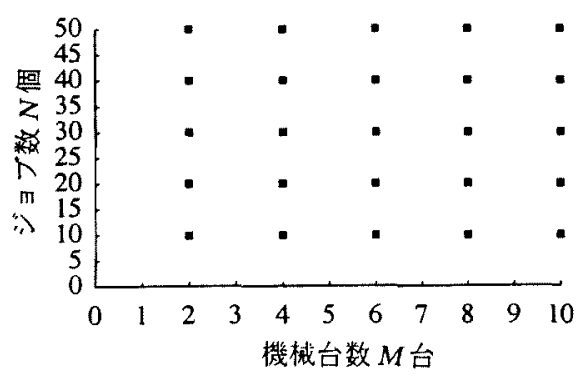

図2学習に用いたスケジューリング問題 の規模の分布

Fig. 2. The distribution of $(M, N)$ of the scheduling problems used for the training of the neural network.
ル・ネットワーク予測值を $100 \%$ 利用しようとするもの である。すなわち、ニューラルネットワークを 4 層とし， 秋期余裕予测值と入力の閒に含まれると考えられる,より 複雑な非楾形の関数関係を表現できるようにする一方，中 間層 1 層当たりのニューロン数を堿らし，また，ジョブ数 $N$ や機械数 $M$ なと，複数のジョブに対して同一の值を示す ような入力を省くことにより，学習効率を高め，納期余裕 の予測精度を上げるよう工夫を行う。

ジョブショップ・スケジューリング問題は，状況に応じ てどのジョブを選択するかを決めるから，本来は離散的な 強い非線形を示すと推定される。例えば，あるジョブの理 論的納期余栄と実漈的納期余裕との関数関保を考えてみよ 5。もし, 理論的納期余裕が極端に短ければ，スケジュー リンダに際してこのジョブが最優先で選択される。この状 洗では，実際的納期余裕は理論的納期余裕に等しい。ここ で作業時間が短くなって理論的納期余裕が長くなると，実 際的納期余裕も比例して增加する。ところが, 理論的納期 余裕が他のジョブの理論的納期余裕よりも長くなると、こ の他のジョブが優先されて恝行されるため, 実漈的納期余 裕が突然短くなる場合が生じる。この状況で, 理論的納期 余裕を長くしていくと，実漈的納期余裕も増加する傾向に あるが，さらに別のジョブの理論的納期余裕よりも長くな ると, 再び, 実際的納期余裕は短くなり, 以下, 同様の変 化を繰り返す。この傾向は, ジョブ毎に, またスケジュー リング問題每に大きく異なり、ニューラルネットワークは， これらの非線形特性を平均化した特性を学習するものと思 われる。この非線形特性は, 平均納期余裕など他の変数の 影整を受けて, 複雑な関数形として表されるものと考えら れ， 3 層よりも 4 層のニューラルネットワークのほうがよ り精密にこれを表現できると考えられる。

ニューロン数を少なくする理由は，一つには，ニューラ ルネットワークを 4 層とすることにより，非線形特性の表 現能力が增し, 一層当たりのニューロン数を減らせること による。いま一つには，著者の一部がニューラルネットワ ークをロボット制御に応用した研究 ${ }^{181}$ の経験によれば, 二 ューロン数が多すぎると，教示点のみを過度に忠実に含も うとする複雑な非線形曲面をニューラルネットワークの入 出力関数として学習してしまい, 構成したい統計的に平滑 化された非線形曲面が学習されず，教示点以外の入力に対 する補間機能が失われてしまう現象が見られた。本研究に おいても，教示点のバラッキを平滑化して，教示点以外の 入力に対して適切な内挿を行える関数関保を構成する最適 なニューロン数があると考えられ，4 層としたことにより この最適数が前報よりも堿少したものと考えられる。

まえがきで述べたように，他のジョブとの競合がある寒 祭のスケジュール上の納期余裕を教師信号として与え, 二 ニーラルネットワークの学習を行う。使用するルールは, 納期遅れ改善に効果のある発見的ルールの中で, 最も基整

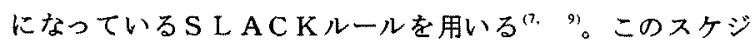
ュールは, ニューラルネットワークの納期余裕推測值に基 
づいて S L A C Kルールを適用して作られるのが望ましい が、一番最初は, ニューラルネットワークの学習が行われ ていないのでこの方法を用いることができない。そこで， 最初の教師データを作るためのスケジュールは, 従来のS L ACKルールの使用法どおり他のジョブとの競合を考虑 しない理論的納期余裕にS L A C Kルールを適用して作成

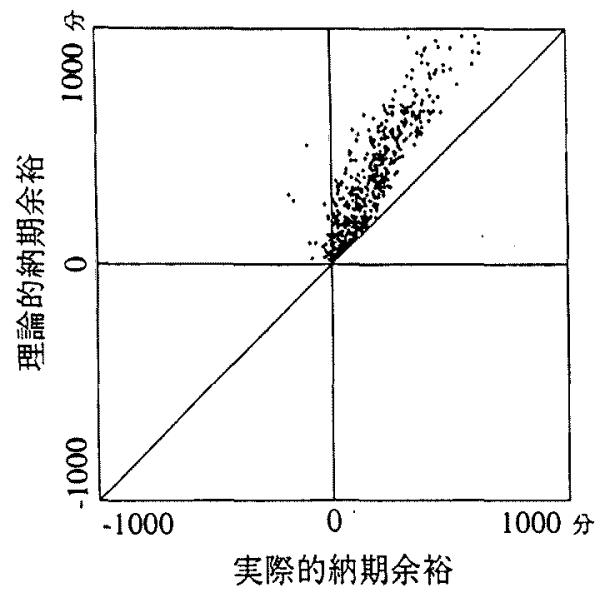

図3 SLACKルールで用いられる理論的納期 余裕と作成されたスケジュール上の実 際的納期余裕との比較

Fig. 3. The comparison of the theoretical margin used by SLACK rule and the actual margin in the obtained schedules.

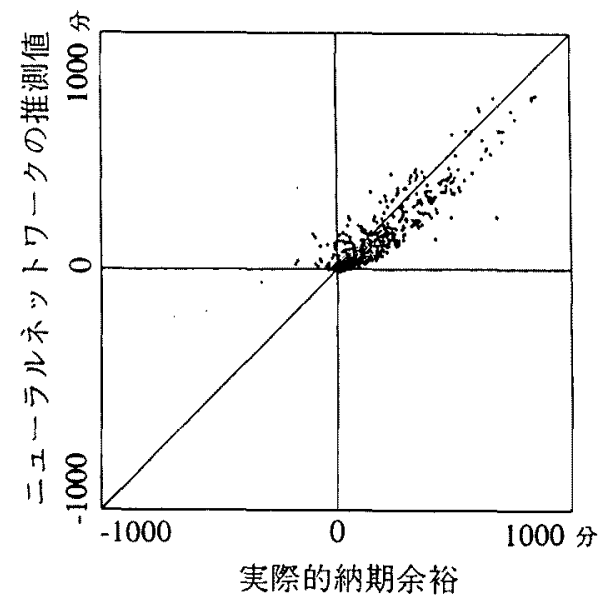

図4 学習後のニューラルネットワークの 出力值と教師信号に用いた実際的納 期余裕の比較

Fig. 4. The comparison of the margin estimated by the neural network after 2000 learning steps and the actual margin used as the training data.
することにした。この場合, 納期余裕予測は, 他のジョブ との䀧合を考庙せずに行われるが，出来上がったスケジュ 一ルは，他のジョブとの競合を考虑したものになっている。 次善の策ではあるが，このスケジュール上の競合を考慮に 入れた納期余裕を教師信号として用い，スタジュールに関 わる諸変数との関保を学習させる。このニューラルネット ワークの学習結果は, 従来のS L A C Kルールを用いる方 法で作られるので，十分なものではないが，欺合を考虑し ない理論的納期余裕よりは, 醅合を考慮した実際の納期余 裕に近い值を推定でき，納期遅れなどに関してょり優れた スケジュールを作り出せるものと期待できる。一度, ニュ ーラルネットワークの学習がすめば, 次にこのニューラル ネットワークと S L A C Kルールの組み合わせで作られる 新しいスケジュールから教師信号を作りだし，再学習すれ は，旧来のS L A C Kルールで作られた教師信号に基つか ない,より理想的な方向人学習が進むと期待されるが, 二 れについては，5章で検討する。

最初の学習は, 具体的には, 各機械が作業を終える毎に, 作業待ちのジョブの中から理論的納期余裕の最も短いもの を選んで作業を行うことによりスケジュールを作成する。 各ジョブについて，このスケジュール上で生じた納期余裕 （実祭的納期余裕）を求める。次にこれを納期余裕を予測 するニューラルネットワークの教師信号として与え, 学習 を行う。すなわ，各ジョフ毎の上記に示した入力值を計 算し, ニューラルネットワークに与え, ニューラルネット ワーク出力值と比較し, バックプロパダーション・アルコ リズムにより，各ニューロンのシナプス荷重を変更する。

シミュレーションで用いるスケジューリング問題は，機 械数 $M=2,4,6,8,10, シ ゙ ョ フ ゙$ 数 $N=10$ ， $20 ， 30 ， 40 ， 50$ の計 25 通りの組み合わせに対し て各 1 例つっ用意した。各機城での作業時閒は，5分から 200 分の閒で一様乱数により与えた。ニューラルネット ワークの学習に用いたスケジュール問題の $(M, N)$ の組 み合わせを図 2 に示す。

学習は,これらの25問題中の計 750 のジョブに対し てそれぞ S L A C Kにより得られた納期を教師信号とし， 750 例について 2000 回䜌り返して学習させた。

因 3は，横軸にS L A C Kにより作られたスケジュール が与える実際的納期余裕, 縦軸にそのスケジュール作成あ たって用いられる理論的納期余裕を示している。理論的納 期余裕は，他のジョプ干涉を考境せずに算出されるため， 奏際的納期余裕に比へ, 長い值を示している。图 4 の維軸 は, 学習後のニューラルネットワークの出力值であり，横 軸に示された実際的納期余裕を学習していることが分かる。

\section{4. 納期余裕予測の効果}

まえがきで述べたように，他のジョブとの競合がある実 際のスケジュール上の納期余裕を教師信号として与え, 二 ニーラルネットワークの学習を行う。使用するルールは, 納期遅れ改善に効果のある発見的ルールの中で, 最も基磷 
になっているSＬＡＣＫルールを適用しけ.9，作業待ちの ジョブの中から納期余裕予测值の最も短いものを選び出し て加エすることにより，スケジュールを作成した。

スケジューリング問題は, 機械台数, ジョブ数を固定し た上で，2 章，3 章で述べたニューラル・ネットワークの 教示問題を作るの同様の方法で，乱数を用いて作成した。

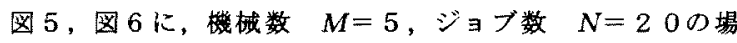

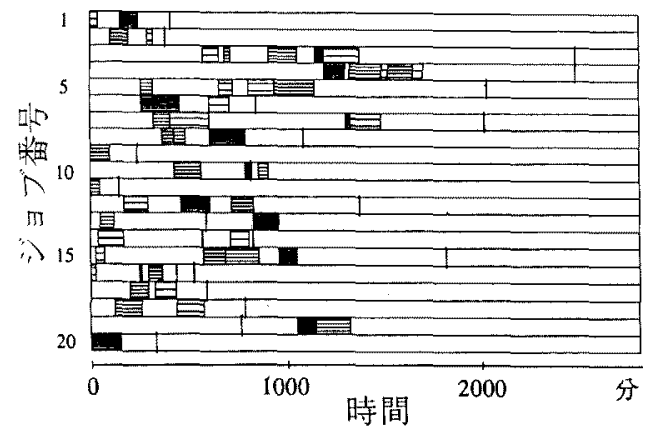

機械番号

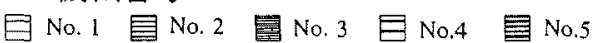
1: 納期

図 5 理論的納期余裕を用いる従来の SLACKルールによるスケジュー リング結果例

Fig. 5. An example of the schedule obtained by the ordinary SLACK rule based on the simple theoretical estimation of margins.

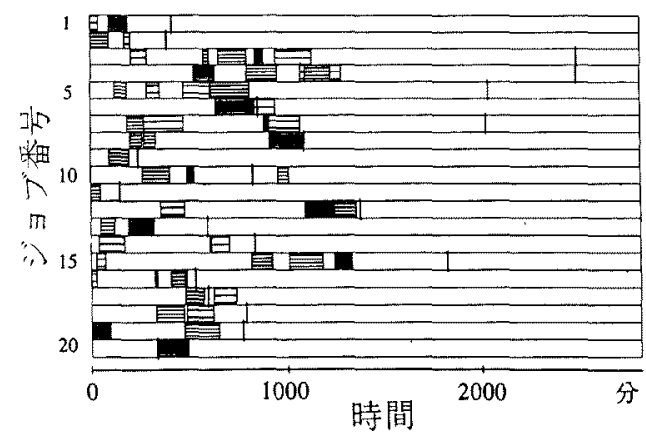

機械番号

曰 No.1 圆 No. 2 糞 No.3 No.4 No.5 I: 納期

\section{図 6 ニューラルネットワークの納期余裕 予測を用いたスケジューリング例}

Fig. 6. An example of the schedule obtained by the proposed SLACK rule based on the margins estimated by the neural network.
合のスケジューリング結果の 1 例をガントチャートで表現 し，理論的納期余裕を用いる従来のスケジューリング結果 との比較を示した。図 5 は従来のS L A C Kルールによる スケジューリング結果であり，図 6 は納期余裕予測に二ュ ーラルネットワークを用いた場合の結果を示す。図 5 中で, ジョブ19が561分の最大納期遅れを生じているのに対 し，図6では，最大納期遅れはジョブ20による379分 となり，182 分の短縮が見られる。

本研究は，种期遅九改善に效果のある S L A C Kルール の改善に主眼をおいているが，納期遅れ以外の他の特性が 悪くなったりしないかについて検討しておく必要がある。 例えば，総処理時間に注目すると，図 5 ではジョブ4が最 後に完了し時刻 1709 分に作業を終えているのに对し， 図6ではジョブ12が最後に処理され時刻 1358 分に作 業が終了しており，やはり 351 分の短縮となっている。

なお，図5，図6で与えられた問題の一例と同一の問题 に対するガントチャートを前報でも示しているが(16, 17), 前 報の場合および今回の場合とも全く同じガントチャートが 得られている。すなわち，前報に比へ，本報では一つだけ のニューラルネットワークを使って前報同様の効果が得ら れたとも言えるが，さらに本報の方法では理論的納期余裕 を用いる従来の方法よりも㤠いスケジュールを作る確率は 低くなるので，平均でみると，より一層の改善がなされる。 例えば前報で示した最大納期遅れの改善率（最大納期遅れ の短樎時間を最大納期遅れで割った比率。前報参照)で比 較すると， $(M, N)=(5,20) ，(10 ， 50) k$ 对して前報ではそれぞれ7.6\%，5．1\%であったのに 対し，今回の方法は，約 $85 \%$ および $71 \%$ という結果が 得られている。

図 7 および図 8 は， $(M, N)=(5,20)$ および $(M$, $N)=\left(\begin{array}{ll}10 & 0\end{array} 50\right)$ のスケジューリング問題各ぬ 100 例に对して求めた結果について，各々最大納期迤れと総処 理時間を棒グラフで表わして比較したものである。6本の ダラフのうち，左端は従来のS L A C Kルールを用いた場 合，左から 2 番目はここで提案した方法を用いた場合を示 す。いずれも 100 例に対する平均值で，最大納期遅れが $(M, N)=(5,20)$ の場合で 103 分から15分に 約 88 分の短䑿（短維の最大值 692 分, 最小值一 105 分；一は逆に延長したことを意味），(M, N) = (10， 50 ）の場合で 381 分から112分へと 269 分の短縮 (短樎の最大值 1330 分, 最小值 -115 分)，総処 理時間が $(M, N)=(5,20)$ の埸合で1968分か ら1958 分に約 10 分の短縮（短縮の最大值 297 分, 最小值 -247 分 $),(M, N)=(10,50)$ の場 合で4509分から4489 分へと20分の短樎（短縮の 最大值 702 分, 最小值 -916 分) となっている。本 研究では，S L A C K を使った場合の納期遅れ改善を目指 しており，当然ながら最大納期晕れについて提案の方法が 効果の高いことが示されており，また，他の特性である総 処理時間も悪化することはなく, 幾分改善されることがわ 
かる。

ここで取り上げた $(M, N)=\left(\begin{array}{ll}1 & 0\end{array}, 50\right)$ は, 図 2 に見られるように, ニューラルネットワークの学習に用い た最大規模の問題であるにもかかわらず，納期余裕予測が ある程度有効に機能していることがわかる。

以上の結果から，理論的納期余裕に対して，実際的納期 余裕を一つのニューラルネットワークで予測して S L A C Kルールを適用する方法が従来のS L A C Kルールよりも 効果があることがわかる。ここでは，納期遅れ改善に勃果 のあるルールの中で最も基本的なS L A C Kルールと組み 合わせたが，Lo○k A h e a d 法や他のS L A C K を 改善した納期余裕を判定基隻に用いるルール(18) と組み合わ せることも可能である。

次に他の手法やスケジューリング問題との比較について 簡単に述べる。図 7,8 右端 S L / R P T, SL+SP Tで表示しているのは, S L A C Kルールの改良手法(19)を 使って本研究で用いた問題を解いた結果を示している。 $\mathrm{L} / \mathrm{R}$ P T は各ジョブの理論的納期余裕をそのジョブの残 り処理時間で割った值の短い順に優先させる規則, S L + S P T は, 上記 S L / R P T で用いる值かS P T ルールで 用いる処理時間のうち, どちらか短い方をとって，その短 いジョブ順に優先させるルールである。これらのルールを 用いた場合, 総処理時間は本研究で提案の方法より短くな っているが，目的とする最大納期遅れについては従来のS $\mathrm{LACK}$ A ルー゙解く場合よりもかえって長くなっている。 スケジューリング問題に関してベンチマークテスト問題 を解いて比較する方法も考えられるが(20.21, 22), 最大納期暑 れ最小化について解いたベンチマーク問題は見つけられず， ここでは含めなかった。スケジューリング問題は，1 1 題 1 題特性が大きく異なるので，本研究で行ったように乱数を 用いて客観的に多数の問題を作成して解く方法も十分な妥 当性を与えるものと考えられる。

最適解を解いて比較することも考えられるが，ここで検 砷した程度の問題について納期遅れ最小化を目指すB A B 法 (Branch and Bound 法) を開発するには多大な労力と計 算時間を要し，現在のところ求め得ないでいる。機械数 3 ， ジョブ数 3 程度の例題について試みて見たところ, 従来の S L A C K, 提案の方法, 最適解で納期遅れが 10 分, 5 分, 0 分, 総処理時閒が 60 分, 55 分, 50 分となった。 しかし、ニューラルネットワークによる納期余裕予測は, 比較的問題が複雑なところで有効と思われ, この結果から そのまま類推できるとは思えないけれども最適解に至るに はまだまだ改善の余地があるものと思われる。

なお，本研究において 3 章で述へた 750 の問題につい て2000回のニューラルネットワークの学習に要する時 閒は約 10 分, また $(M, N)=\left(\begin{array}{llll}1 & 0\end{array}, 50\right)$ の問題 1 例をニューラルネットワークによる納期予湘と S L A C K によってスケジューリングする時間は約 4 秒である。従来 のS L A C Kのみでスケジューリングするのに要する時閒 は約 2 秒である。ここで用いた計算機はワークステーショ
ンSPARC I PXである。すなわち，1ジョブあたり の学習時閒は，0８秒であり, 将来, 新しい教育課題が 与えられた場合にこれをオンライン(9)で学習していくとし てもその負担はわずかである。

\section{5. 納期余裕の再学習}

前章まででは、ニューラルネットワークの教師信号とし て, 理論的納期余裕を用いた従来のS L A C Kルールによ って作られたスケジュール上の実際的納期余裕を用いた。 これにより学習したニューラルネットワークの有効性が前 章で示されたが，次はこの競合の元での納期余裕を予測 し ながら作られたスケジュール結果を用いて再学習すれは，

より優れた結果が期待される。

そこで，4章で述べた、ニューラルネットワークを用い て作られたスケジュール上での他のジョブとの競合も考盧 に入れた害際的納期余裕を新たに教師信号として用いるこ とにより, 再度ニューラルネットワークの学習を試みた。 前回の学習で用いたジョブ 750 例について新たに教師信 号を求め, 同じく 750 例を 2000 回絹り返して学習を 行った。

再学習したニューラルネットワークを用いて, 前章と同 じ, $(M, N)=(5,20)$ および $(M, N)=\left(\begin{array}{l}10 ，\end{array}\right.$ $50)$ のスケジューリング問題各々 100 例について求め た結果についての平均值を, 図 7, 図8のダラフ中央に示 す。この再学習の結果, 最大納期羊れが $(M, N)=(5$, $20 ）$ の問題で 15 分から 11 分に 4 分短宿し, $(M, N)$ $=\left(\begin{array}{lll}1 & 0\end{array}, 50\right)$ の問題で 111 分から 108 分に 3 分 短樎した。また, 絰処理時間も, それぞれ1958 分から 1943 分に15 分, 4489 分から4439分に50分 短縮するのが見られた。

以上の結果から再学習による改善はそれほど大きくはな く, 従来のS LACKルールの結果を用いて学習したニュ ーラルネットワークのままでもかなりよい予測ができてい ることがわかる。これら再学習の操作はアルゴリズム化し て自動化できるので，オペレータの手閒をとることはない。 また, 一旦, これらの学習終了後は, 実際の納期余裕が求 まる毎にニューラルネットワークの学習をオンラインで繶 け，より樑い経験をニューラルネットワークに積ませるこ とが期待できる。

\section{6. むすび}

ジョブ・ショップ・スケジューリング問題において, 最 大納期遅れの少ない準最適解を求めるのに効果のある $\mathrm{S} \mathrm{L}$ A C Kルールを用いる発見的手法について, 従来の単純な 納期余裕の計算に基づく方法に代って，ニューラルネット ワークを用いてジョブ間の競合の影暃なども考虑して納期 余裕を予測する方法を租み合わせる方式を提案した前報 ‘ 6.ネ2では, $10-20-1$ の構成の 3 層のニューラルネ ットワークを用いたが，予測の信頼性が低いため，信頼性 を評価する第 2 のニューラルネットワークを導入して，信 
頼性の低い時は，従来どおりの計算結果を用い极ばならな 加た。今回, ニューラルネットワークを 4 層化し, ニュ 一ロン数も調整して 8-8-8-1の構成として，予測の 信頼性を高め,この納期余﨏予測のニューラルネットワー クのみを用いて，効果のあることを示した。

まず，従来のS L A CKルールを用いて作ら机るスケジ メーリング結果により学習したニューラルネットワークを 用いた場合に有效性が確㑇され，さらに，そのスケジュー

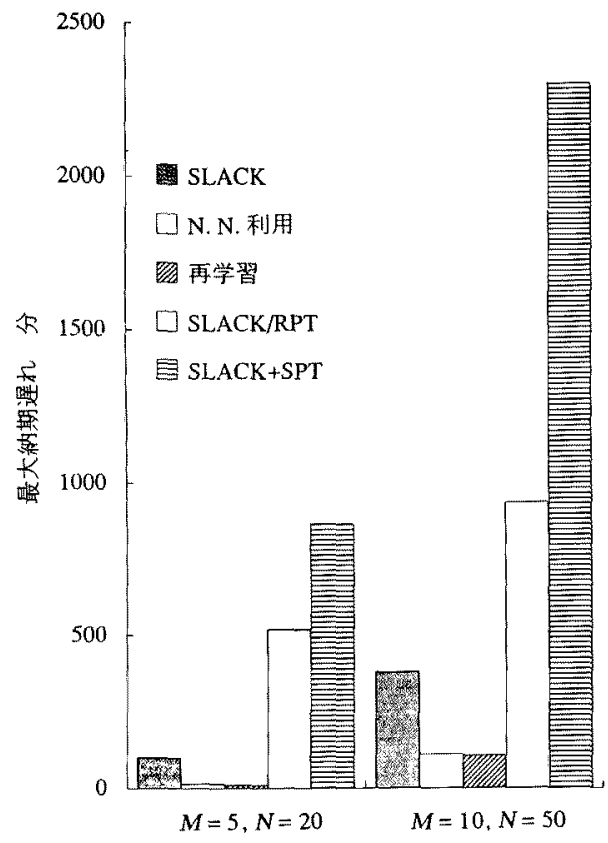

図7 最大納期遅れに関する従来法と提案法 の比較

Fig. 7. Comparison of the maximum latenesses to due-date obtained by the ordinary SLACK and its revised rule and by the proposed method.

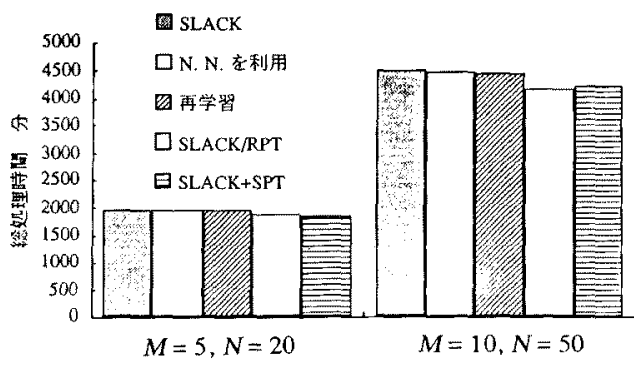

图8 総処理時閒に関する従来法と提案法の 比較

Fig. 8. Comparison of the maximum completed times obtained by the ordinary SLACK and its revised rule and by the proposed method.
リング結果を用いて再学習を行うと，一層改彭する傾向が 見られることを示した。

今後, ニューラルネットワータへの入カとしてより有意 な信号を見いだして利用すること, 学習パターンの選び方 の㭘封，最適なニューラルネットワークの構成方法の検郡， 再学習の収束性の検討により,さらに改善を進めることが できるものと思われる。

(平成 6 年 8 月 30 日受付, 同 6 年11月30日再受付)

\section{文献}

(1) T. Watanabe: "Advanced Studies in Flexible Automation", Proc. of 6th Int. Conf. on CAD/ CAM, Robotics and Factories of the Future, Southbank Press (1991)

(2) T. Watanabe: "Intelligent Management and Manufacturing Systems", Advances in Management (ed. G Lasker), Int. Inst. for Advanced Studies in Systems Research and Cybernetics, pp. 91-96 (1993)

(3) T. Watanabe: "Flexible Manufacturing Systems Software", Concise Encyclopedia of Software Engineering (ed. P. Morris and B. Tamm), Pergamon Press, London, pp. 132-135 (1993)

(4) A. Villa \& T.Watanabe: "Production Management: Beyond the Dichotomy between "Push" and "Pull"", Computer Integrated Manufacturing Systems, Vol.6, No. 1, pp. 53-63 (1993)

(5) B. Giffler, \& G. L. Thompson: "Algorithms for Solving Production Scheduling Problems", Operation Research, Vol.8, pp. 487-503 (1960)

（6）鍋島一郎：”スケジューリング理論”，森北出版, pp. 187-229 (1974)

(7) 人見勝人："生産管理工学”，コロナ社, pp. 79-83, pp. 136-149 (1978)

（8）黒田充, 田部勉, 圆川隆夫, 中根甚一郎：“生産管理”, 朝倉書店, pp. 86-97 (1989)

(9) T. Wat anabe, \& M. Sakamoto: "On-line Scheduling for Adaptive Control Machine Tools in FMS", Robotics and Computer Integrated Manufacturing, Vol. 2, No.1, pp. 56-64 (1986)

(10)P. Bunnag, \& S. B. Smith: "Multifact or Priority Rule for Jobshop Scheduling Using Computer Search", IIE Transactions, pp. 141-146 (1985)

(11)T. Watanabe, R. Fujii, K. Kido, \& K. Inagami: "Self Modification of Scheduling in Production", Proc. of IFAC Int. Workshop on Decisional Structures in Automated Manu facturing, pp. 71-80 (1989)

(12)T. Watanabe, K. Kido, \& R. Fujii: "The Automatic Improvement of Job-shop scheduling and New 
Dispatching Rules", Proc. 1990 Japan - U.S.A. Symposium on Flexible Automation, ISCIE, Kyoto, pp. $1133-1138$ (1990)

(13)J. Somlo, \& T. Watanabe: "Job-shop Scheduling of FMS - The Optimization Approach", Proc. of 1992 Japan-US Symp. on Flexible Automation, ASME, New York, pp.447-454 (1992)

(14)T. Watanabe, H. Tokumaru, Y. Nakajima, \& Y. Hashimoto: "Job-shop Scheduling Using Fuzzy Interference to Take Profit into Account", 1992 JapanUS Symp. on Flexible Automation, ASME, New York, pp. 423-427 (1992)

(15)T. Watanabe, H.Tokumaru, Y. Hashimoto \& Y. Hirose: "Job-shop Scheduling Based on the Estimation of Margins to Due-Dates by Using a Neural Network", Proc. of 1992 Pacific Conference on Manufacturing, pp. 516-522 (1992)

(16)T. Watanabe, H.Tokumaru, \& Y. Hashimoto: "Jobshop Scheduling Using Neural Networks", Preprint of 12 th World Congress of the IFAC, Vol. 6, pp. 345348 (1993)

(17)T. Watanabe, H. Tokumaru, \& Y. Hashimoto: "Jobshop Scheduling Using Neural Networks", Control Engineering Practice, Vol. 1, No. 6, pp. 957-961 (1993)

(18)黒川圭一, 渡部透, 得丸英勝, 川野亨, 久保誠吾, 山 川恵嗣, 河田健一：”ニューラルネットワークを用い たロボットマニピュレータの手先位置・姿勢誤差の補 償”, システム制御情報学会論女誌, Vol. 6, No. 5, pp. 213-222 (1993)

(19)M. Moser, \& S. Engell: "A Survey of Priority Rules for FMS Scheduling and Their Performance for the Benchmark Problem", Proc. of the 31th CDC, pp. 392-397 (1992)

(20)A. Kusiak, \& J. Ahn: "Priority Rule-Based Scheduling", Proc. of the 1990 Summer Computer Simulation Conf., pp. 1119-1124 (1990)

(21)P. Brucker, \& B. Jurisch: "Job-Shop (C codes)", European Journal of Research 57, pp. 132-133 (1992)

(22)P.Brucker, \& B. Jurisch: "A New Lower Bound for the Job-Shop Scheduling Problem", European Journal of Research 64, pp. 156-167 (1993)

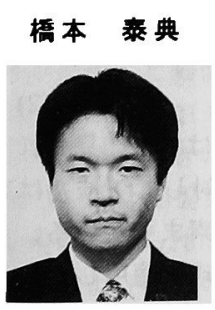

(学生員) 1968 年9月 26 日生。 91 年 3 月立命館大学理工学部情報工学 科卒業。9 3 年 3 月同大学院理工学研究 科修士課程情報工学専攻修了。同年 4 月 より同大学院理工学研究科博士課程情報 工学を専攻し, 現在に至る。生産システ ム, ニューラルネットワークおよび遺伝
アルゴリズムを用いた最適化問題などに関心を持つ。電気 学会, システム制御情報学会, 日本機械学会会員。

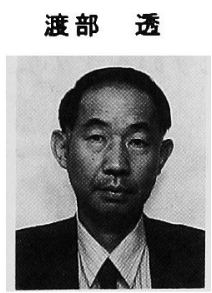

（正貝） 1942 年 6 月 11 日生。 65 年 3 月京都大学工学部精密工学科卒 業。6 7 年 3 月京都大学大学院工学研究 科精密工学専攻修士課程修了。同年 4 月 京都大学工学部助手。 86 年 11 月同才 ートメーション研究施設助教授。87年 4 月同大学院応用システム科学専攻助教 授兼任。 88 年 4 月立命館大学理工学部情報工学科教授。 91 年 4 月同計算機センター長兼任。94 年 4 月より同総 合情報センター副センター長兼任, 現在に至る。ロボット や NCなどの計算機制御，生産の管理と制御，CAD／C $\mathrm{I} \mathrm{M} / \mathrm{CE}, \mathrm{N} \mathrm{N} / \mathrm{GA}$ 応用, 並列処理計算機などの研 究に従事。京都大学工学博士。8 6 年日本自動制御協会 (現 システム制御情報学会) 椹木記念論文賞受賞。電気学会, システム制御情報学会, 情報処理学会, 日本機械学会, 計 測自動制御学会, 精密工学会, 日本ロボット学会, A S M E，IＩＡＳなどの会員。

西川郁子 1961 年 11 月 1 日生。 84 年 3 月京

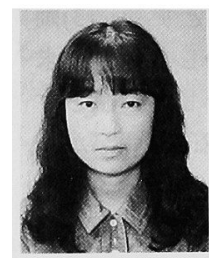
都大学理学部物理学科卒業。90 年 3 月 同大学院博士課程単位取得退学。同年 4 月神戸大学大学院自然科学研究科助手。 93 年 4 月立命館大学理工学部情報工学 科助手, 現在に至る。博士 (理学)。二 ューラルネットワーク, 非線形振動など の非線形動力学の研究に従事。日本物理学会, システム制 御情報学会, 日本神経回路学会などの会員。

得丸英勝 1927 年 8 月 7 日生。 50 年京都大学

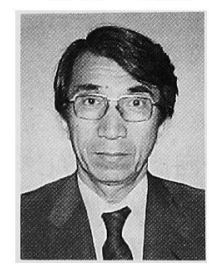
工学部応用物理学教室卒業。5 1 年 4 月 同大学工学部応用物理学教室助手。5 3 年 7 月同講師。 56 年 3 月同航空工学教 室助教授。6 2 年 4 月数理工学教室教授。 87 年 5 月応用システム科学教室教授。 89 年 4 月同大学工学部長を兼任。9 1 年 4 月立命館大学理工学部情報工学科教授となり, 94 年 4 月同大学理工学部長を兼任, 現在に至る。 59 年工学博 士。7 0 年計測自動制御学会論文賞, 81 年日本自動制御 協会（現システム制御情報学会）椹木記念賞論文賞を受賞。 計測自動制御学会, 日本機械学会, 日本材料学会, 日本レ オロジー学会, 日本騷音制御工学会, エネルギー・資源研 究会, 日本防災システム協会, 日本工学アカデミー会員。 